\title{
Peluang Pemanfaatan Limbah Minyak Goreng Sebagai Bahah Baku Biodiesel di Makassar
}

\author{
Machmud Syam*, A. Erwin E. Putra, Novriany Amaliyah, Azwar Hayat \\ Departemen Teknik Mesin, Fakultas Teknik, Universitas Hasanuddin \\ Poros Malino Km. 6, Bontomarannu, Gowa Sulawesi Selatan, Indonesia. \\ machmudsyam@gmail.com*
}

\begin{abstract}
Abstrak
Mengkomsumsi minyak jelantah dengan bilangan peroksida 20-40 meq/kg yang setara dengan minyak jelantah rumah tangga yang diberikan secara rutin menyebabkan kerusakan oksidatif, merangsang proses peradangan hati, perlemakan hati atau steatosis dan menyebabkan kerusakan oksidatif DNA sehingga perlu disosialisaikan kepada masyarakat. Makassar sebagai kota metropolitan memiliki potensi minyak jelantah sekiditnya 17.600 liter per hari dan kebanyakan direcycle menjadi minyak goreng bodong untuk diperjual belikan pada kisaran harga Rp 5.000 sampai Rp.7.000 per liter merupakan ancaman pada kualitas kesehatan masyarakat. Transformasi minyak jelantah menjadi biodiesel oleh CV. Garuda Energy Nusantara (Gen- Oil) baru mencapai 400 liter per hari atau setara 2.000 liter per hari biodiesel B20 dengan kualitas performansi yang lebih unggul dibanding solar produk pertamina. Bila skema harga jual B-20 GenOil Rp 5.000 per liter kepada nelayan dapat memberikan keuntungan setidaknya Rp.22.000.000 per bulan dan akan lebih besar lagi bilamana dijual dengan harga standar industri. Selain itu juga bahwa upaya Transformasi minyak jelantah menjadi biodiesel membuka peluang kerja baru dan transformasi minyak jelantah menjadi biodiesel dapat dilakukan dengan teknologi dan dalam skala industri rumah tangga.
\end{abstract}

Kata Kunci: Minyak Jelantah; Biodiesel; Prospek Usaha; Peluang Bekerja; Green Energy.

\section{Pendahuluan}

Inpres No. 1 dan Perpres No. 5 Tahun 2006 menterjemahkan biofuel sebagai bahan bakar nabati $(\mathrm{BBN})$. Bahan bakar nabati atau biofuel adalah setiap bahan bakar baik padatan, cairan ataupun gas yang dihasilkan dari bahan-bahan organik. Biofuel dapat dihasilkan secara langsung dari tanaman atau secara tidak langsung dari limbah industri, komersial, domestik atau pertanian. Ada tiga cara untuk pembuatan biofuel yaitu: 1. pembakaran limbah organik kering (seperti buangan rumah tangga, limbah industri dan pertanian); 2. fermentasi limbah basah (seperti kotoran hewan) tanpa oksigen untuk menghasilkan biogas (mengandung hingga 60 persen metana), atau fermentasi tebu atau jagung untuk menghasilkan alkohol dan ester, dan energi dari hutan (menghasilkan kayu dari tanaman yang cepat tumbuh sebagai bahan bakar) dan 3. mengurai molekul trigliserida dari minyak jelantah menggunakan metanol atau etanol dan dibantu katalisator (Wikipedia, 2010). Biodiesel dikenal sebagai bahan bakar yang ramah lingkungan dan dapat diperbarui. Biodiesel dibuat dari hasil transesterifikasi minyak tumbuhan atau lemak hewan dengan metanol atau etanol. Biodiesel yang diproduksi dari minyak tumbuhan atau lemak hewan umumnya lebih mahal dibanding bahan bakar diesel konvensional. Mengingat hal tersebut maka biodiesel dapat saja dibuat dari minyak nabati yang tidak harus baru, seperti minyak jelantah (minyak bekas penggorengan). Potensi minyak jelantah di Makassar diperkirakan sebesar 17.600 liter per hari yang berasal dari restoran dan industri (Tribun Timur, 2016). Minyak bekas penggorengan ini dikuasai oleh oknum tertentu dan diperjual belikan kepada pengusaha minyak goreng bodong untuk di recycle lalu diperjualbelikan kembali sebagai minyak goreng bodong seharga Rp 5.000 sampai Rp 7.000 per liter kepada mayarakat utamanya dari para pengusaha gorengan di pinggir jalan. Harga ini lebih murah dari harga minyak goreng curah dengan harga rata-rata Rp 9.000 per liter di Pasar Pannampu Makassar. 
Penggunaan kembali dari minyak goreng bodong dapat memberi resiko buruk bagi kesehatan sehingga perlu pengawasan yang ketat mekanisme pemusnahannya. Menurut Andi Hilmi Mutawakkil, chief executive officer (CEO) Genoil, perusahaan yang bergerak di bidang industri pengolahan minyak biodiesel. Mengkonsumsi minyak jelantah berpotensi menghasilkan penyakit degeneratif seperti hipertensi, kanker, dan penyakit-penyakit lainnya. Penelitian dari dr. Maria memaparkan penggunaan minyak jelantah dengan bilangan peroksida $20-40 \mathrm{meq} / \mathrm{kg}$ yang setara dengan minyak jelantah rumah tangga yang diberikan setiap hari selama 16 minggu menyebabkan kerusakan oksidatif, merangsang proses peradangan hati, perlemakan hati atau steatosis dan menyebabkan kerusakan oksidatif DNA. Kesadaran akan dampak buruk penggunaan kembali minyak bekas gorengan membuat Andi Hilmi dan kawan-kawan termotivasi mendirikan pabrik pengolah minyak jelantah menjadi biodiesel yang potensinya cukup besar itu, Sri Wahyuni (2011). Pabriknya kini sudah sanggup memproduksi 400 liter per hari dan dijual kepada nelayan di Paotere dengan harga bersaing. Pengembangan biodiesel di dunia sudah dilakukan sejak tahun 1980-an sehingga pada saat ini di beberapa bagian dunia telah dilakukan komersialisasi. Industri biodiesel secara umum bisa dikatakan cukup sederhana, tidak memerlukan unit-unit operasi dengan tingkat kerumitan maupun resiko yang tinggi. Industri biodiesel dapat diadakan dalam skala kecil, sehingga bisnisnya bisa dilakukan pada skala- skala koperasi dan keuntungannya bisa langsung dinikmati oleh lingkungannya. Penelitian ini mengkaji peluang bisnis dari pemanfaatan minyak bekas penggorengan sebagai bahan baku pada pembuatan biodiesel khususnya di kota Makassar dan mengambil CV. Garuda Energi Nusantara (GEN-Oil) sebagai objek kajian kelayakan usaha. Berdasarkan uraian pada pendahuluan, maka dirumuskan permasalahan dari penelitian ini adalah sebagai berikut:

(1) Bagaimana kelayakan bisnis biodiesel dari minyak jelantah di CV. Garuda Energi Nusantara (GEN-Oil) dilihat dari aspek non-finansial meliputi aspek pasar, aspek sosial, ekonomi dan budaya serta aspek lingkungan?

(2) Bagaimana kelayakan bisnis biodiesel dari minyak jelantah CV. Garuda Energi Nusantara (GEN-Oil) dilihat dari aspek finansial?

(3) Bagaimana kelayakan kualialtas biodiesel dari minyak jelantah?

Untuk menjawab rumusan masalah diatas maka ditetapkan tujuan dari penelitian ini adalah:

(1) Menganalisis kelayakan bisnis biodiesel dari minyak jelantah di CV. Garuda Energi Nusantara (GEN-Oil) dilihat dari aspek non-finansial meliputi aspek pasar, aspek sosial, ekonomi dan budaya serta aspek lingkungan.

(2) Menganalisis kelayakan bisnis biodiesel dari minyak jelantah CV. Garuda Energi Nusantara (GEN-Oil) dilihat dari aspek finansial.

(3) Menganalisis kelayakan kualitas biodiesel dari minyak jelantah sebagai bahan bakar

\section{Latar Belakang Teori}

\subsection{Keuntungan dan Kelemahan Biodiesel}

Menurut Tri Yuswidjajanto, Peneliti Lembaga Afiliasi Penelitian dan Industri (LAPI) Institut Teknologi Bandung (ITB). Biodiesel memiliki sejumlah keuntungan yaitu dapat diperbaharui karena merupakan produk pertania; memiliki cetane number yang tinggi; volatile rendah dan bebas sulfur (SOx); serta memungkinkan diproduksi dalam skala industri kecil, sehingga dapat menggerakkan ekonomi pedesaan. Disamping itu, biodiesel lebih mudah terurai (biodegradable) oleh mikroorganisme dibanding minyak mineral serta dapat menghemat penggunaan minyak solar, 
yang berarti mengurangi ketergantungan impor bahan bakar minyak. Sedangkan kelemahannya antara lain memiliki viskositas lebih kental, sehingga pengabutan butir-butir menjadi lebih besar; memiliki kadar air tinggi, sehingga mudah terbentuk jamur dan mengendap di filter bahan bakar membuat tenaga mesin menjadi drop; memiliki kandungan yang dapat bereaksi pada material yang terbuat dari karet alam, misalnya karet-karet seal pada mesin getas sehingga. beresiko pada kerusakan mesin yang lebih parah (Hanif, 2009). Kelemahan lainnya adalah memiliki kadar asam yang cukup besar. sehingga dikhawatirkan menyebabkan oksidasi dan berpotensi merusak komponen mesin walaupun telah melalui proses netralisasi bahan bakar nabati. Bertolak dari keuntungan dan kelemahan di atas maka pemakaian biodiesel sebagai bahan bakar belum dapat sepenuhnya dipakai sebagai pengganti solar. Bahan bakar biofuel yang diproduksi PT. Pertamina dengan merek dagang B10 adalah bahan bakar dengan kandungan minyak solar 90\% dan 10\% minyak sawit. Dan berdasarkan Permen ESDM No 12 Tahun 2015, kandungan minyak sawit dinaikkan menjadi 20 persen (B20) pada biodiesel atau biosolar yang sudah dipasarkan sejak awal tahun 2016. Langkah diversifikasi energi ini tentu patut didukung dengan tujuan untuk mengurangi ketergantungan terhadap BBM, namun demikian para pengusaha biodiesel ataupun masyarakat pengguna perlu diberi advokasi serta bimbingan teknis agar kebijakan ini cukup aman, mengingat Bahan Bakar Nabati (BBN) memiliki kandungan asam. Toyota sudah pernah melalukan test penggunaan B20 di Innova dan Fortuner sejauh 100 ribu kilometer dengan waktu 9 bulan. Hasilnya sama sekali tidak ada masalah di mobil-mobil itu. Penggunaan B20 ini, konsumsi memang sedikit lebih boros, tapi ruang bakar menjadi lebih bersih. Ini semua berdasar hasil test. Sedang hasil test drive penggunaan B20 terhadap Mitsubishi Pajero Sport Exceed belum ada laporan resmi (Firina, 2010).

\subsection{Persyaratan umum kualitas Biodiesel}

Biodiesel dari minyak jelantah harus memenuhi baku mutu standar agar penggunaannya sebagai bahan bakar pada kendaraan bermotor tetap aman bagi kendaraan ataupun kepada penggunanya. SNI-04-7182-2006 mensyaratkan 19 item standar yang harus dipenuhi. Sembilan item standar kualitas bahan bakar penggant solar yang amat penting adalah:

(1) Berat jenis $\left(850-890 \mathrm{~kg} / \mathrm{m}^{3}\right)$ pada suhu $40 \mathrm{C}$.

Jika biodiesel mempunyai massa jenis melebihi ketentuan, akan terjadi reaksi tidak sempurna pada konversi minyak nabati. Biodiesel dengan mutu seperti ini seharusnya tidak digunakan untuk mesin diesel karena akan meningkatkan keausan mesin, emisi, dan menyebabkan kerusakan pada mesin.

(2) Viskositas $(2.3-2.6 \mathrm{cSt})$ pada suhu $40 \mathrm{C}$.

Viskositas yang tinggi atau fluida yang masih lebih kental akan mengakibatkan kecepatan aliran lebih lambat sehingga proses derajat atomisasi bahan bakar akan terlambat pada ruang bakar.

(3) Angka Cetana (minimum 51).

Angka Cetana menggambarkan kualitas bahan bakar untuk menahan auto ignition sebelum arus propagasi nyala sampai kepadanya. Penggunaan biodiesel dengan Angka Cetana kurang dari 51 memberi peluang terjadinya detonasi dan memperburuk kinerja mesin.

(4) Kadar air (0.05\%).

Makin kecil kadar air dalam minyak maka mutunya akan semakin baik pula karena akan memperkecil terjadinya hidrolisis yang dapat menyebabkan kenaikan kadar asam lemak bebas, kandungan air dalam bahan bakar dapat juga menyebabkan turunnya panas 
pembakaran, berbusa dan bersifat korosif jika bereaksi dengan sulfur karena akan membentuk asam [1].

(5) Bilangan asam (maks $0.8 \mathrm{mg} \mathrm{KOH} / \mathrm{g}$ ).

Angka asam yang tinggi merupakan indikator biodiesel masih mengandung asam lemak bebas. Berarti, biodiesel bersifat korosif dan dapat menimbulkan kerak pada injektor.

(6) Gliserol bebas $(0.02 \%)$.

Gliserol bebas merupakan produk samping dari reaksi transesterifikasi selama pembuatan biodiesel. Keberadaan gliserol dan gliserida dapat membahayakan mesin diesel, terutama akibat adanya gugus $\mathrm{OH}$ yang secara kimiawi agresif terhadap logam bukan besi dan campuran krom.

(7) Flash Point (minimum $100 \mathrm{C}$ ).

Flash Point menunjukkan kualitas bahan bakar untuk dapat menerima tekanan kompresi yang tinggi tanpa terjadi auto ignition sebelum berakhir langkah kompresi.

(8) Residu karbon (maks 0,02\% massa).

Residu karbon menunjukkan perilaku bahan bakar untuk melekat pada dinding ruang bakar atau pada dinding selinder setelah mengalami pembakaran. Biodisel dengan residu karbon yang tinggi akan meningkatkan biaya maintenance dan berpotensi mesin mengalami detonasi terutama pada putaran rendah.

(9) Bilangan iod (maksimum $115 \mathrm{ppm}$ ).

Derajat ketidakjenuhan (ikatan rangkap) pada bahan bakar biodiesel dinyatakan oleh Bilangan Iod. Biodiesel dengan kandungan bilangan iod yang tinggi akan mengakibatkan tendensi polimerisasi dan pembentukan deposit pada injector noozle dan cincin piston pada saat mulai pembakaran [2].

(10) Kalor Pembakaran (min. $35.000 \mathrm{~kJ} / \mathrm{kg}$ )

Kalor pembakaran menunjukkan potensi energi dari biodiesel yang dapat dibebaskan selama proses pembakaran. Bila angka ini rendah mengisyaratkan pemakaian bahan bakar dari mesin akan lebih boros.

Rangkuman sifat fisik dan sifat kimia dari biodiesel minyak jelantah menurut hasil pengukuran dari sejumlah peneliti disajikan dalam Tabel 1.

Tabel 1. Sifat Fisik dan Kimia Biodiesel Jelantah

\begin{tabular}{|l|c|c|}
\hline Parameter & Satuan & Nilai \\
\hline Berat Jenis & $\mathrm{Kg} / \mathrm{m} 3$ & $874-880$ \\
\hline Viscositas & $\mathrm{cSt}$ & $5.77-6.06$ \\
\hline Kadar air & $\%$ & $0.01-0.16$ \\
\hline Bilangan Asam & $\mathrm{mgKOH} / \mathrm{g}$ & $0.39-1.84$ \\
\hline Gliserol Bebas & $\%$ & $0.01-0.02$ \\
\hline Kadar Ester Alkil & $\%$ & $96.5-101.2$ \\
\hline Bilangan Iod & $\mathrm{ppm}$ & $39-115$ \\
\hline Kalor Pembakaran & $\mathrm{kJ} / \mathrm{kg}$ & $36744-38500$ \\
\hline Bilangan Cetana & - & $51-55$ \\
\hline
\end{tabular}




\section{Metode Penelitian}

Penelitian ini menggunakan metode observasi lapangan dengan teknik wawancara mendalam terhadap saudara Ahmad Sahwawi selaku manajer teknik CV. Garuda Energi Nusantara (GENOil) dikombinasi pengamatan terhadap distribusi penggunaan minyak jelantah (bekas penggorengan) pada sejumlah pasar tradisional di kota Makassar dalam upaya mengkaji permasalahan pertama dan kedua. Untuk mengkaji permasahan ketiga, digunakan metode kajian pustaka terhadap sejumlah jurnal hasil penelitian biodiesel dari minyak jelantah.

\section{Hasil dan Diskusi}

Analisis kelayakan usaha dilakukan untuk menentukan apakah suatu usaha layak atau tidak untuk dijalankan. Analisis kelayakan usaha pengolahan minyak jelantah (minyak bekas penggorengan) menjadi biodiesel produk CV. Garuda Energi Nusantara (GEN-Oil) dilakukan dengan mengkaji aspek non finansial dan aspek finansial. Analisis aspek non finansial meliputi aspek pasar, aspek sosial ekonomi serta aspek kesehatan dan lingkungan. Sedang analisis aspek finansial dilakukan dengan menggunakan kriteria-kriteria penilaian investasi dan analisis laba-rugi guna memperoleh unit cost biodiesel minyak jelantah yang prospektif.

\subsection{Analisis aspek Pasar}

Produk biodiesel dari CV. Garuda Energi Nusantara selama ini dipasarkan kepada nelayan di Paotere dengan harga Rp 5.000 per liter terserap penuh dikarenakan harganya Rp 650 dibawah harga solar bersubsidi. Harga itu sangat jauh dari harga solar industri ataupun harga MFO. Untuk wilayah III pertamina harga solar industri ataupun harga MFO masing-masing Rp.8.400 dan Rp.6.600. Bertolak dari selisih harga yang cukup signifikan terhadap harga solar industri ataupun harga MFO maka peluang pemasaran B-20 dari CV Garuda Energi Nusantara terbuka lebar. Tantangan terberat yang dihadapi adalah penyediaan bahan baku minyak jelantah sebagai akibat dari persaingan dengan pengusaha minyak goreng bodong yang relatif lebih mudah dan murah biaya produksinya.

\subsection{Aspek sosial ekonomi}

Dalam menjalan usahanya, CV. Garuda Energi Nusantara mempekerjakan preman pasar ataupun penganggur sebagai tenaga kolektor sebagai penghasilan tambahan dari para kolektor. CV. Garuda Energi Nusantara mempekerjakan 30 orang, 25 orang diantaranya bertugas sebagai kolektor dan 5 orang sebagai tenaga di pabrik pengolahan yang diberi upah sesuai UMR Makassar ditambah bonus serta asuransi. Upah yang relatif sama kepada para founder. Dari sudut pandang sosial ekonomi saya melihat bahwa kehadiran CV Garuda Energi Nusantara cukup memberi konstribusi positif dalam mengatasi masalah pengangguran.

\subsection{Analisis aspek kesehatan dan lingkungan}

Sebagaimana telah diketahui bahwa penggunaan kembali minyak jelantah dalam bentuk minyak goreng bodong potensial menimbulkan penyakit-penyakit generatif dan secara tidak langsung menurunkan derajat kesehatan masyarakat. Usaha transformasi minyak jelantah menjadi biodiesel merupakan suatu upaya dalam mereduksi sumber potensial pemicu penyakit-penyakit generatif bawaan minyak jelantah. Tranformasi ini juga sekaligus memperbaiki mutu lingkungan mengingat keunggulan dari biodiesel. 


\subsection{Analisis aspek finansial}

Berangkat dari modal hasil gadai sejumlah barang para founder sebesar Rp.360.000.000 dan motivasi technopreneurship dari ke enam foundernya. Mereka bersepakat pada tahun 2014 memdirikan CV Garuda Energi Nusantara atau CV GEN-Oil dengan visi MEMBANGUN BANGSA YANG MANDIRI ENERGI. Kini CV. GEN-Oil telah mengelola 37.800-liter minyak jelantah per bulan yang menghasil omset sebesar Rp 173.880.000. Setelah dikurangi dengan biaya produksi masih tersisa penghasilan bersih senilai Rp 22.000.000 perbulan. Angka ini masih cukup jauh di atas pembayaran cicilan untuk masa pinjaman 5 tahun. Kalkulasi berdasarkan kriteria-kriteria investasi dan analisis laba-rugi menunjukkan bahwa usaha dari CV GEN-Oil layak secara investasi. Tekad membangun bangsa yang mandiri energi dari para founder membawa mereka keluar sebagai juara event Social Intrpreneure Ide untuk Indonesia, mendapat beasiswa senilai Rp 100.000.000 dan mewakili Indonesia pada Konferensi sekaligus mengunjungi perusahaan Biodiesel di Inggris pada November 2016. Keberhasilan menjadi juara pada even tersebut di atas membuktikan bahwa usaha ini amat menjanjikan.

\subsection{Analisis aspek kualitas biodiesel GEN-Oil}

Hasil tes kualitas dari biodiesel GEN-Oil yang secara periodik dilakukan pada PT. SUCOPINDO. Terdapat 16 item kualitas yang menunjukkan bahwa biodiesel produk CV Garuda Energi Nusantara memenuhi persyaratan kualitas sehingga peneliti anjurkan agar membuka pasar yang lebih luas.

\section{Kesimpulan}

Berdasarkan hasil penelitian dan analisis yang telah dilakukan maka dapat disimpulkan sebagai berikut:

(1) Kualitas biodiesel produksi CV Garuda Energi Nusantara (GEN-Oil) memenuhi Standar Biodiesel Indonesia.

(2) Potensi minyak jelantah di Makassar cukup besar yaitu 17.600 liter per hari harus diawasi rantai pemusnahannya karena bisa berdampak negatif pada kesehatan dan lingkungan

(3) Tranformasi minyak jelantah menjadi biodiesel perlu didukung untuk mengurangi ketergantungan pada BBM

(4) Diperlukan upaya sosialisasi kepada masyarakat agar dampak negatif mengkonsumsi minyak jelantah pada kesehatan dapat diminimalisir.

(5) Upaya Transformasi minyak jelantah menjadi biodiesel membuka peluang kerja baru.

(6) Transformasi minyak jelantah menjadi biodiesel dapat dilakukan dengan teknologi dan dalam skala industri rumah tangga.

\section{Ucapan Terima Kasih}

Penghargaan yang setinggi-tingginya kepada LP2M Universitas Hasanuddin atas Hibah Pengabdian Masyarakat Skim Ipteks bagi Masyarakat (IbM) 2017 yang telah mendukung terlaksananya kegiatan ini. 


\section{Daftar Pustaka}

Dwi Widjanarko, Abdurrahman dan Hadromi, (2010). Pengujian Alat Pengolah Limbah Munyak Go-Reng Menjadi Biodiesel Sebagai Bahan Bakar Alternatif Motor Diesel, FT UNNES, Jurnal Penelitian Saintek Vol.15 No.1.

Hanif, (2009), Analisis Sifat Fisik Dan Kimia Biodiesel Dari Minyak Jelantah Sebagai Bahan Bakar Alternatif Motor Diesel, Politeknik Negeri Padang, Jurnal Teknik Mesin Vol.6, No.2.

Firina Amelia, Retnaningsih dan Irni Rahmayani Johan, (2010). Perilaku Peng-Gunaan Minyak Goreng Serta Pengaruhnya Terhadap Keikut- Sertaan Program Pengumpulan Minyak Jelantah Di Kota Bogo, IPB, Jurnal Departemen Ilmu Keluarga dan Konsumen, Vol.3 No. 2.

Sri Wahyuni, Sri Kadarwati dan Latifah, (2011). Sintesis Biodiesel Dari Minyak Jelantah Sebagai Sumber Energi Alternatif Solar, UNNES, Jurnal Sainteknol Vol.9 No.1.

Perdana Surya Putra Widodo, (2011). Analisis Kelayakan Usaha Pengolahan Minyak Jelantah (Waste Cooking Oil) Menjadi Biodiesel, IPB

Syamsidar HS, (2016). Pembuatan Dan Uji Kualitas Minyak Jelantah, Fak. Sains dan Teknologi UIN Makassar (e- journal).

Tribun Timur (2016). Koran Cetakan 28 September 2016.

Wikipedia (2010) 